\title{
A novel, mitogen-activated nuclear kinase is related to a Drosophila developmental regulator
}

\author{
Gerald V. Denis and Michael R. Green ${ }^{1}$ \\ Howard Hughes Medical Institute, Program in Molecular Medicine, University of Massachusetts Medical Center, Worcester, \\ Massachusetts 01605 USA
}

\begin{abstract}
Although the ultimate targets of many signal transduction pathways are nuclear transcription factors, the vast majority of known protein kinases are cytosolic. Here, we report on a novel human kinase that is present exclusively in the nucleus. Kinase activity is increased upon cellular proliferation and is markedly elevated in patients with acute and chronic lymphocytic leukemias. We have identified a human gene that encodes this nuclear kinase and find that it is closely related to Drosophila female sterile homeotic $(f s h)$, a developmental regulator with no known biochemical activity. Collectively, these results suggest that this nuclear kinase is a component of a signal transduction pathway that plays a role in Drosophila development and human growth control.
\end{abstract}

[Key Words: Signal transduction; kinases; Drosophila; leukemia; trithorax]

Received March 28, 1995; revised version accepted December 8, 1995.

A variety of extracellular signals can regulate the transcriptional activity of particular structural genes. Specific nuclear-localized transcription factors are believed to be the ultimate targets of diverse' ${ }^{1}$ signal transduction pathways (for reviews, see Hunter and Karin 1992; Jackson 1992; Karin 1994). Two mechanisms have been described by which signals that regulate transcription reach the nucleus. In the first mechanism, in response to an appropriate signal, the transcription factor itself translocates from the cytosol to the nucleus. The prototype transcription factor that uses this mechanism is NF- $\kappa B$ (Baeuerle and Baltimore 1988a,b), but other examples include members of the STAT family (Darnell et al. 1994), SV40 T antigen (Rihs et al. 1991), SWI5 (Moll et al. 1991), Dorsal (Rushlow and Warrior 1992), v-Jun (Chida and Vogt 1992), ISGF3 (Kilgour and Anderson 1994), steroid hormone receptors (Kuiper and Brinkmann 1994), and NFAT (Liu 1993) (for review, see Whiteside and Goodbourn 1993). A second mechanism involves the nuclear translocation of a cytosolic kinase, which in some cases directly phosphorylates the nuclear transcription factor target. For example, nuclear forms of protein kinase A (Nigg et al. 1985), protein kinase C (Leach et al. 1989), p42 ${ }^{\text {mapk }}$ and p44 $^{\text {mapk }}$ (MAP) kinases (Lenormand et al. 1993), and ribosomal S6 (RSK) kinase (Chen et al. 1992) can be detected after mitogenic stimulation.

It remains possible, however, that there are kinases that are downstream targets of cytosolic signaling pathways but that are principally nuclear in localization. Lit-

${ }^{1}$ Corresponding author. tle is known about such nuclear kinases, although some candidates include the $\mathrm{c}-\mathrm{Abl}$ protein tyrosine kinase (Kipreos and Wang 1992), a DNA-dependent protein kinase (Jackson et al. 1990; Finnie et al. 1993), and a cell cycle-dependent complex containing $\mathrm{p} 33^{\text {cdk2 }}$ kinase (Devoto et al. 1992; Faha et al. 1992). Furthermore, kinases that phosphorylate the carboxy-terminal domain (CTD) of RNA polymerase II, including the general transcription factor TFIIH, have been characterized (Feaver et al. 1991; Lu et al. 1992). However, a role for these kinases in signal transduction has not been established.

In this paper we describe a novel nuclear kinase that has significant homology with fsh, a Drosophila protein known to be important in embryonic pattern formation (Haynes et al. 1989). The autophosphorylation activity of this kinase was correlated with cellular proliferation and was elevated in patients with acute and chronic lymphocytic leukemias.

\section{Results}

\section{Identification of a $90-k D$ nuclear kinase}

To identify nuclear kinases, polypeptides in HeLa nuclear or cytosolic extracts were separated by polyacrylamide gel electrophoresis (SDS-PAGE), electroblotted to nitrocellulose, denatured, renatured, and incubated with $\left[\gamma^{-32} \mathrm{P}\right]$ ATP. This assay detects autologous phosphorylation, which is frequently correlated with kinase autoactivation (Hunter 1987). Figure 1 shows that one major and several minor polypeptides were autophosphorylated. The major multiplet, which had an apparent mobility of $\sim 90 \mathrm{kD}$, was present in nuclear extract but absent from cytosolic extract. Several experiments suggest 


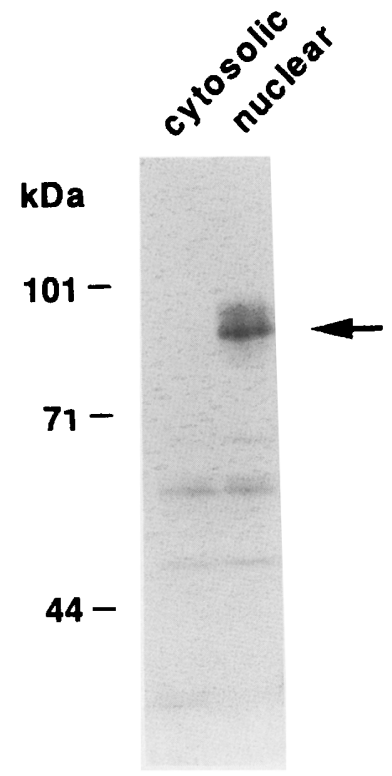

Figure 1. Identification of a $90-\mathrm{kD}$ nuclear kinase. Proteins $\mid 50$ $\mu \mathrm{g}$ ) from HeLa nuclear and cytosolic extracts were prepared, then subjected to SDS-PAGE and renaturation on nitrocellulose. Renatured autophosphorylation activities are shown, with an arrow indicating the $90-\mathrm{kD}$ multiplet. Blots probed with $\left[\alpha^{-32} \mathrm{P}\right]$ ATP showed background radioactivity but no discrete bands (data not shown).

that these various $\sim 90 \mathrm{kD}$ polypeptides are differentially phosphorylated and, as a result, can be chromatographically separated (data not shown; see below). For convenience of discussion, we will refer to these multiple bands as "the $90-\mathrm{kD}$ nuclear kinase". Several other autophosphorylation activities were detected, but these were equally present in nuclear and cytosolic fractions. In addition to HeLa cells, we have detected the $90-\mathrm{kD}$ nuclear kinase in stimulated human peripheral blood lymphocytes (PBLs) and cell lines from humans [A431, Jurkat, EBV-transformed human B cell $(32 D)$, HUT78, and CEM], rodents (Mv1Lu, 3T3-L1, and $\mathrm{CHO})$, and monkeys (CV-1 and COS-7) (data not shown).

\section{The 90-kD nuclear kinase has a unique specificity}

To determine whether the $90-\mathrm{kD}$ autophosphorylation activity could phosphorylate an exogenous protein substrate, the kinase was partially purified (see below), resolved by SDS-PAGE, transferred to nitrocellulose, and renatured. A nitrocellulose strip containing the renatured kinase was then added to a reaction mixture containing myelin basic protein (MBP) and $\left[\gamma^{-32} \mathrm{P}\right] \mathrm{ATP}$. Figure $2 \mathrm{~A}$ shows that the immobilized $90-\mathrm{kD}$ nuclear kinase phosphorylated MBP. We then used this assay to determine the specificity of the kinase. Of several common peptide substrates tested, the $90-\mathrm{kD}$ kinase phosphorylated only peptide substrates for smooth muscle myosin light-chain kinase (KKRPQRATSNVFS) and cAMP-dependent protein kinase (LRRASLG) (Table 1). This pattern distinguishes the $90-\mathrm{kD}$ nuclear kinase from other kinases described to date (Pearson and Kemp 1991 and references therein).

The results of these peptide phosphorylation experiments suggested that the $90-\mathrm{kD}$ nuclear kinase used serine and threonine as phosphoacceptors. To confirm this supposition, we performed phosphoamino acid analysis. Figure $2 B$ shows that the immobilized $90-\mathrm{kD}$ nuclear kinase phosphorylated MBP only on serine. Figure $2 \mathrm{C}$ shows that autophosphorylation occurred equally on serine and threonine. We conclude that the $90-\mathrm{kD}$ enzyme is a serine-threonine kinase.

\section{0-kD nuclear kinase activity is stimulated by agents that promote cellular proliferation}

We then asked whether the $90-\mathrm{kD}$ nuclear kinase was activated by particular signal transduction pathways. To

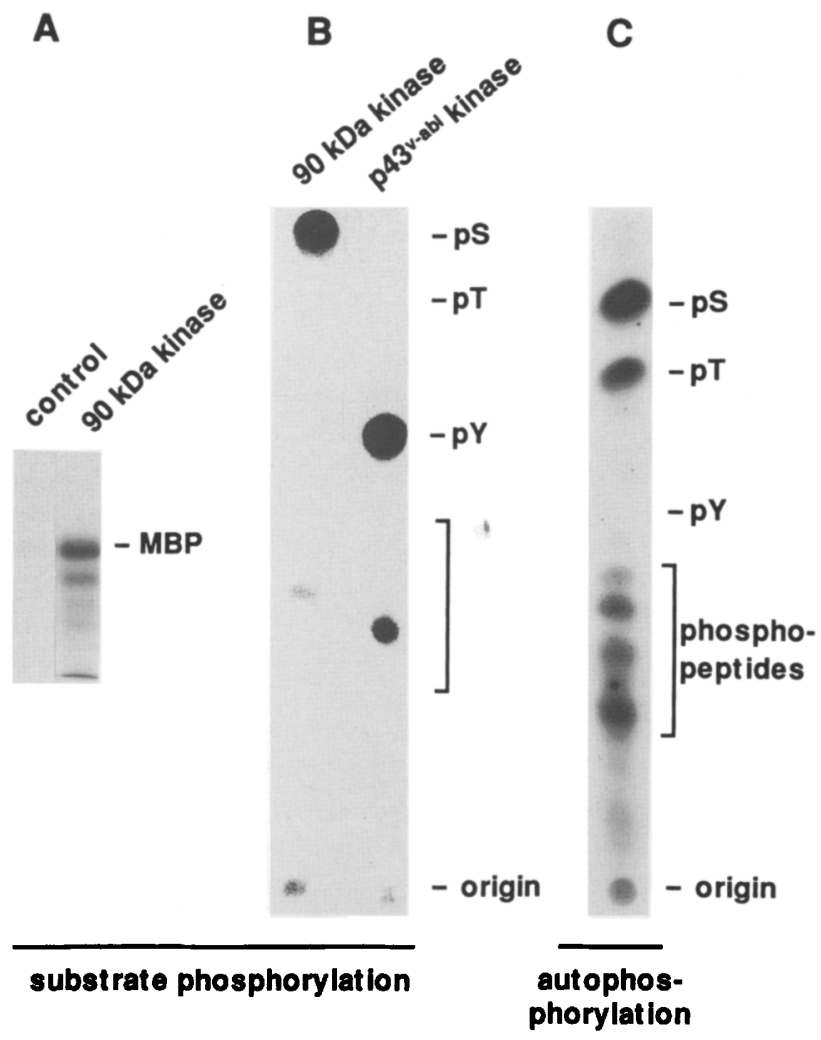

Figure 2. The $90-\mathrm{kD}$ nuclear kinase phosphorylates serine and threonine residues. (A) Purified $90-\mathrm{kD}$ nuclear kinase was resolved by SDS-PAGE, renatured on nitrocellulose, and used to phosphorylate MBP. As a negative control, MBP was incubated under the same conditions with nitrocellulose that did not have immobilized kinase. Activity was $\mathrm{Mg}^{2+}$-dependent; $\mathrm{Mn}^{2+}$ did not substitute (data not shown). (B) Phosphoaminoacids of radiolabeled MBP $(A, r i g h t)$ were determined. The mobilities of authentic phosphoaminoacid standards are indicated. (B,left) MBP phosphorylated with renatured $90-\mathrm{kD}$ kinase. (B,right) MBP phosphorylated with a tyrosine kinase (recombinant $\mathrm{p} 43^{\mathrm{v}-a b 1}$ ). (C) Phosphoamino acids of kinase renatured on a polyvinyldifluoride membrane and autophosphorylated with $\left[\gamma^{32} \mathrm{P}\right] \mathrm{ATP}$. 
Table 1. Peptide substrate specificity of HeLa $90-k D$ nuclear kinase and recombinant RING3 proteins

\begin{tabular}{|c|c|c|c|}
\hline \multirow[b]{3}{*}{ Substrate } & \multirow{2}{*}{$\begin{array}{c}\text { HeLa } \\
(90 \mathrm{kD})\end{array}$} & \multicolumn{2}{|c|}{ RING3 phosphorylated with NE } \\
\hline & & WT & K578A \\
\hline & \multicolumn{3}{|c|}{ kinase activity ( $\%$ of Kemptide control) } \\
\hline Kemptide & $100( \pm 12)$ & $100( \pm 6)$ & $<5$ \\
\hline MLCK & $135( \pm 7)$ & $51( \pm 3)$ & $<5$ \\
\hline tyrk & $11( \pm 1)$ & N.D. & N.D. \\
\hline S6K & $7( \pm 1)$ & $<5$ & $<5$ \\
\hline CaMKII & $<5$ & $<5$ & $<5$ \\
\hline MAPK & $<5$ & N.D. & N.D. \\
\hline CKII & $<5$ & $<5$ & $<5$ \\
\hline PKC & $<5$ & N.D. & $<5$ \\
\hline No substrate & $<5$ & $<5$ & $<5$ \\
\hline
\end{tabular}

The $90-\mathrm{kD}$ kinase was renatured on nitrocellulose after partial purification from HeLa nuclear extract and used to phosphorylate peptides with $\left[\gamma^{-32} \mathrm{P}\right] \mathrm{ATP}$. Recombinant proteins were renatured in polyacrylamide gels. (WT) Wild type; (K578A) site-directed point mutant where catalytic Lys 578 is changed to alanine. Phosphate incorporation was linear through at least 60 $\mathrm{min}$ and $2 \mathrm{mg} / \mathrm{ml}$ of peptide. $100 \%$ represents $\sim 100,000 \mathrm{dpm}$. Peptide substrate sequences are Kemptide (cAMP-dependent protein kinase), LRRASLG; MLCK (myosin light-chain kinase from smooth muscle), KKRPQRATSNVFS; tyrK (tyrosine kinase), Raytide (an analog of gastrin, EGPWLEEEEEAYG); S6K (S6 kinase), RRLSSLRA (S6 peptide); CaMKII (calmodulin-dependent kinase II), PLSRTLSVSS; MAPK (microtubule-associated protein kinase II), APRTPGGRR; CKII (casein kinase II), RRREEETEEE; PKC (protein kinase C), RFARKGSLRQKNV. Duplicate assay; (N.D.) not determined.

determine whether the activity was correlated with cellular proliferation, a serum-responsive cell line, A431, was starved of serum overnight and then provided with $20 \%$ serum for $15 \mathrm{~min}$. Figure 3A shows that autophosphorylation activity was significantly increased in extracts prepared from serum-stimulated cells. In a related experiment, PBLs that were normal and quiescent were cultured in the presence of phytohemagglutinin (PHA) to induce proliferation. Figure $3 \mathrm{~B}$ shows that the $90-\mathrm{kD}$ nuclear kinase activity was significantly increased in response to PHA. We tested several components of serum to determine which, if any, caused this increase. Only interleukin-1 $\alpha$ (IL-1) treatment resulted in significant stimulation (Fig. 3C). Substances that did not increase $90-\mathrm{kD}$ kinase activity included epidermal growth factor, platelet-derived growth factor- $\beta$, acidic fibroblast growth factor, insulin, glucagon, transforming growth factor- $\beta$, and interleukin-2, each of which was tested in an appropriately responsive cell line. Other potential stimuli of 90-kD autophosphorylation, such as herpesvirus infection, heat shock, ultraviolet light, hydrogen peroxide, sodium periodate, sodium vanadate, or cadmium chloride, were similarly ineffective (data not shown). Interestingly, we also found that forskolin, an activator of cAMP-dependent protein kinase pathways, transiently increased kinase activity in the mammalian $\mathrm{T}$-cell line Jurkat (Fig. 3D).
Autophosphorylation of the $90-\mathrm{kD}$ kinase increased sharply $\sim 5$ min after stimulation in $\mathrm{CHO}$ (Fig. $3 \mathrm{C}$ ) or Jurkat (Fig. 3D) cells and declined slightly through 30 min. The rapid time course suggested that a post-translational modification was responsible for the increased activity. Consistent with this idea, autophosphorylation was dramatically reduced when extracts were prepared in the absence of phosphatase inhibitors or were briefly warmed to $37^{\circ} \mathrm{C}$ in the presence of $5 \mathrm{~mm}$ magnesium chloride (data not shown). These results suggest that the $90-\mathrm{kD}$ nuclear kinase is reversibly phosphorylated.

\section{Purification and microsequence analysis of $90-\mathrm{kD}$ nuclear kinase}

We purified the kinase from HeLa nuclear extract according to the scheme diagramed in Figure 4A. The partially purified kinase was resolved by SDS-PAGE, transferred to nitrocellulose, and digested with trypsin. Tryptic peptides were separated by high-pressure liquid

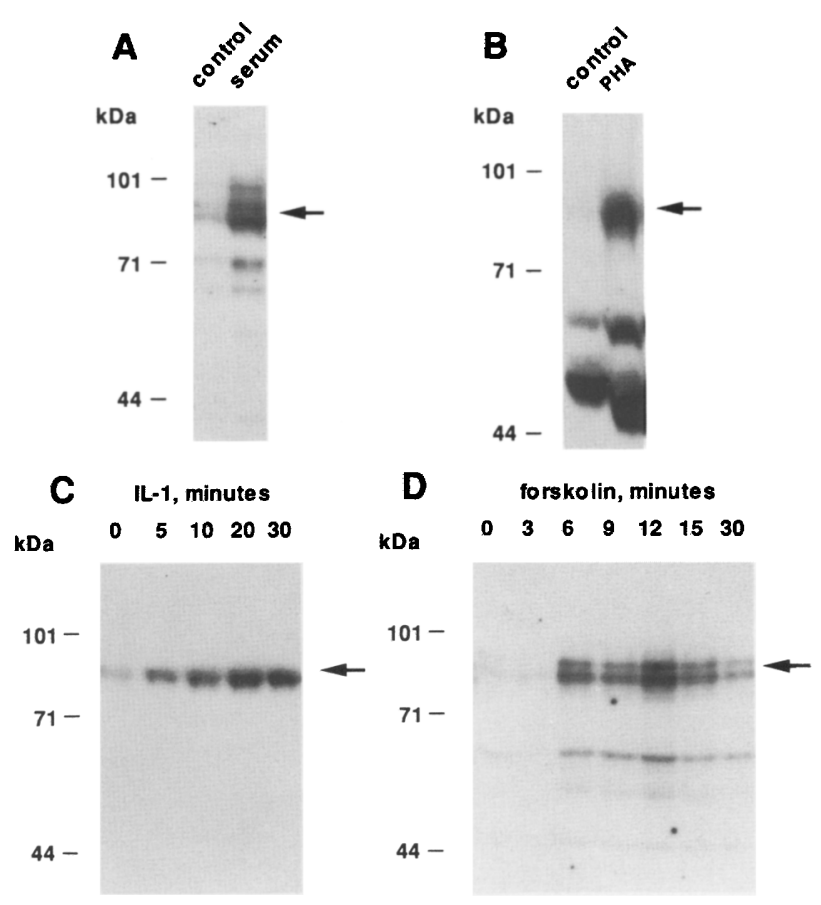

Figure 3. Stimulation of $90-\mathrm{kD}$ autophosphorylation. (A) A431 cells were starved of serum, then treated with control buffer or calf serum $(20 \%)$ for $15 \mathrm{~min}$ at $37^{\circ} \mathrm{C}$. Kinases in nuclear extracts were assayed by renaturation assay. An arrow indicates the 90$\mathrm{kD}$ multiplet. $(B)$ Total PBLs $\left(\sim 10^{7}\right\}$ were isolated from normal, healthy volunteers, suspended in RPMI 1640 with $10 \%$ autologous serum, and cultured for 3 days, either unstimulated or stimulated with $2 \mu \mathrm{g} / \mathrm{ml}$ of PHA. (C) CHO cells were starved of serum, then treated with IL- $1 \alpha(10 \mathrm{ng} / \mathrm{ml})$ for the indicated times. $(D)$ Jurkat cells were stimulated with $50 \mu \mathrm{M}$ forskolin for the indicated times. Stimulated $90-\mathrm{kD}$ kinase activity in Jurkat and $\mathrm{CHO}$ extracts was enriched by application to phosphocellulose and elution with $0.3 \mathrm{M} \mathrm{NaCl}$. Increased autophosphorylation was correlated with increased MBP-directed substrate phosphorylation (results not shown). 
Figure 4. Purification and microsequence analysis. $(A)$ Chromatographic scheme. (B) Microsequence Alignment. Homologous sequences are indicated with boldface type. Bromodomains are indicated with a heavy solid line. PEST scores are indicated in boldface above a broken line that defines a PEST sequence (analyzed with the BASICA-supported program PESTFIND). The putative NLS is indicated with a box. Microsequenced peptides are aligned as pept 1 and pept 2 . Numbering is according to the translated cDNA for $f s h$. Percent conservation of sequence between RING3 and fsh has been reported (Beck et al. 1992).

chromatography (HPLC), and two peptides were microsequenced. The first of these (DSNPDEIEIDFETLKPTTL/ was used to probe the GenBank data base; a match was obtained to the Drosophila homeotic gene, female sterile homeotic ( $f$ sh) (DROFSHB) (Haynes et al. 1989); there were 18 of 19 identities and a conservative $T$ to $S$ substitution. A match was also obtained with the RING3 gene of humans (HUMRING3) (Beck et al. 1992); there were 17 of 19 identities with a conservative $D$ to $E$ substitution and the same $T$ to $S$ substitution as in fsh. RING3, an acronym for "really interesting new gene", was serendipitously discovered during sequencing of the class II region of the human major histocompatibility complex (Beck et al. 1992). The second microsequenced peptide (AVHEQLAALSQAP) matched RING3; there were 12 of 13 identities with a conservative A to G substitution at position 12 . This peptide did not match fsh. Figure $4 \mathrm{~B}$ presents an alignment of fsh and RING3. The calculated molecular mass of RING3 is $83 \mathrm{kD}$, which correlates well with the apparent mobility of the $90-\mathrm{kD}$ phosphoprotein as measured by SDS-PAGE.

\section{Immunoprecipitation and immunofluorescence analysis}

We performed a series of experiments to test whether human RING3 encodes a kinase. First, we raised antisera to recombinant RING3 and asked whether it could immunoprecipitate $90-\mathrm{kD}$ nuclear kinase activity. Figure $5 A$ characterizes the affinity-purified $\alpha$ RING3 polyclonal antibody by immunoblot analysis. The results show that in a HeLa nuclear extract the $\alpha$ RING3 antibody principally detected a $90-\mathrm{kD}$ polypeptide, whose size is consistent with that of the RING3 open reading frame (ORF) (Fig. 4B) and the nuclear autophosphorylation activity. Two other polypeptides of unknown identity were also detected, and, as discussed below, these additional polypeptides could be members of a protein family. Figure 5B shows the immunoprecipitation analysis. Immune complexes were resolved by SDS-PAGE, and activity was determined by renaturation/autophosphorylation. The results show that the $90-\mathrm{kD}$ kinase was immunoprecipitated by the $\alpha$ RING3 antibody but not by preimmune serum. Significantly, the size of the autophosphorylation activity was identical to that of the major polypeptide detected in the immunoblot experiment of Figure 5A. These data strongly support the interpreta-

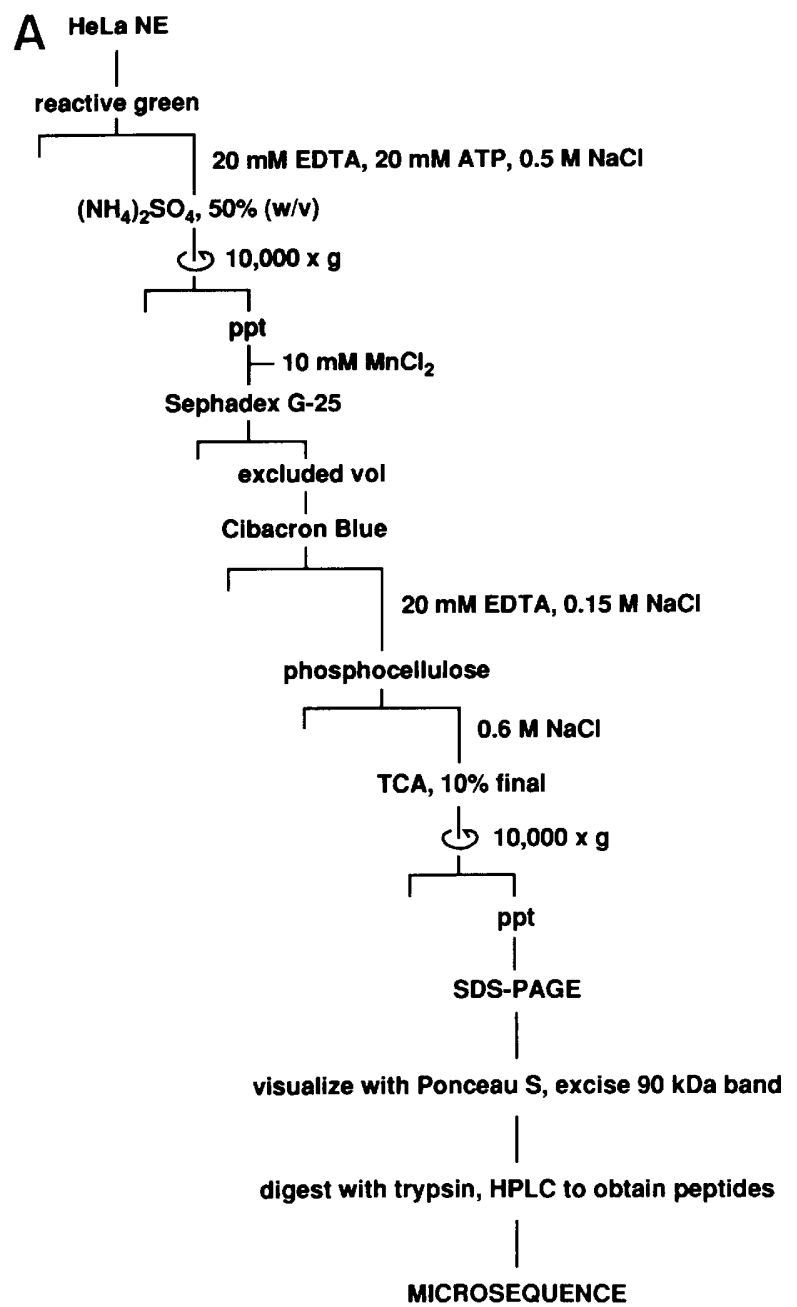

B

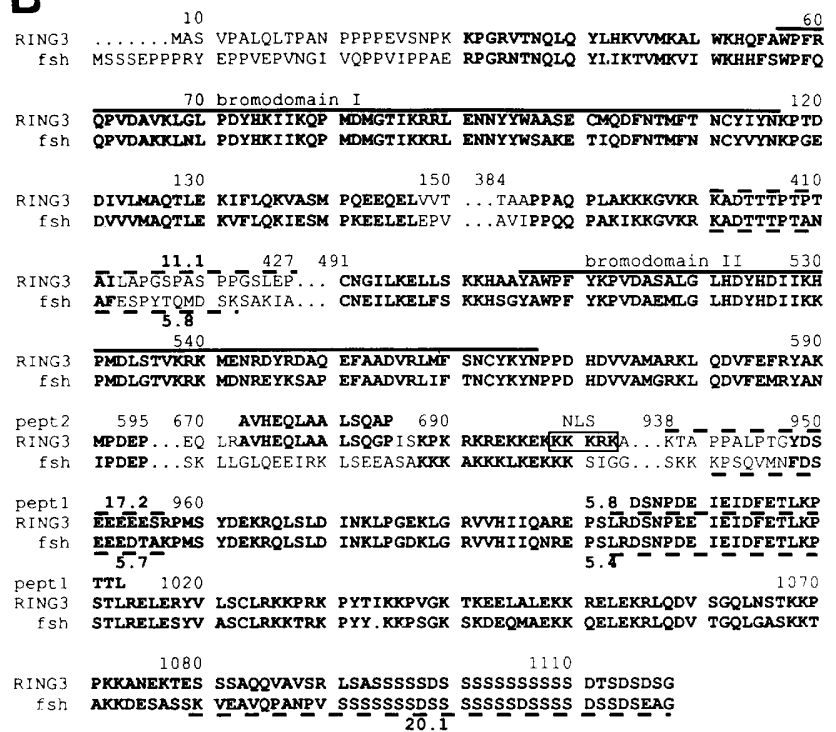

tion that the nuclear autophosphorylation activity results from RING3.

The $\alpha$ RING3 antibody was also used in the indirect immunofluorescence experiment of Figure 5C. RING3 is 
A

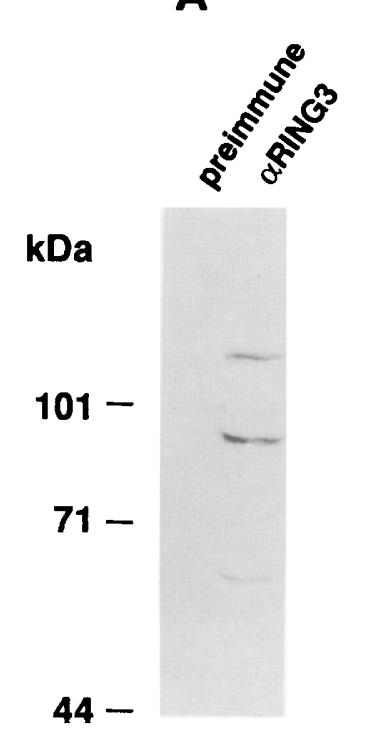

Immunoblot
B

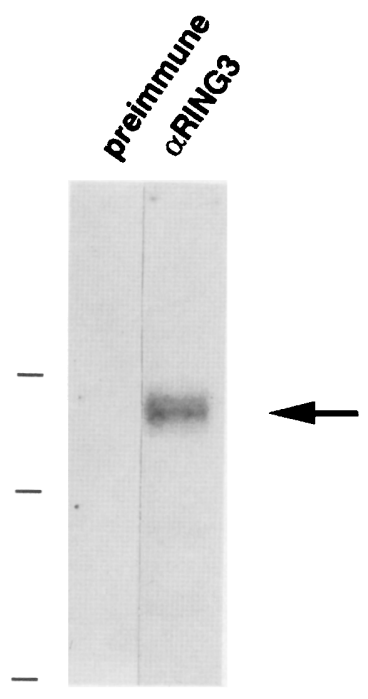

Autophosphorylation

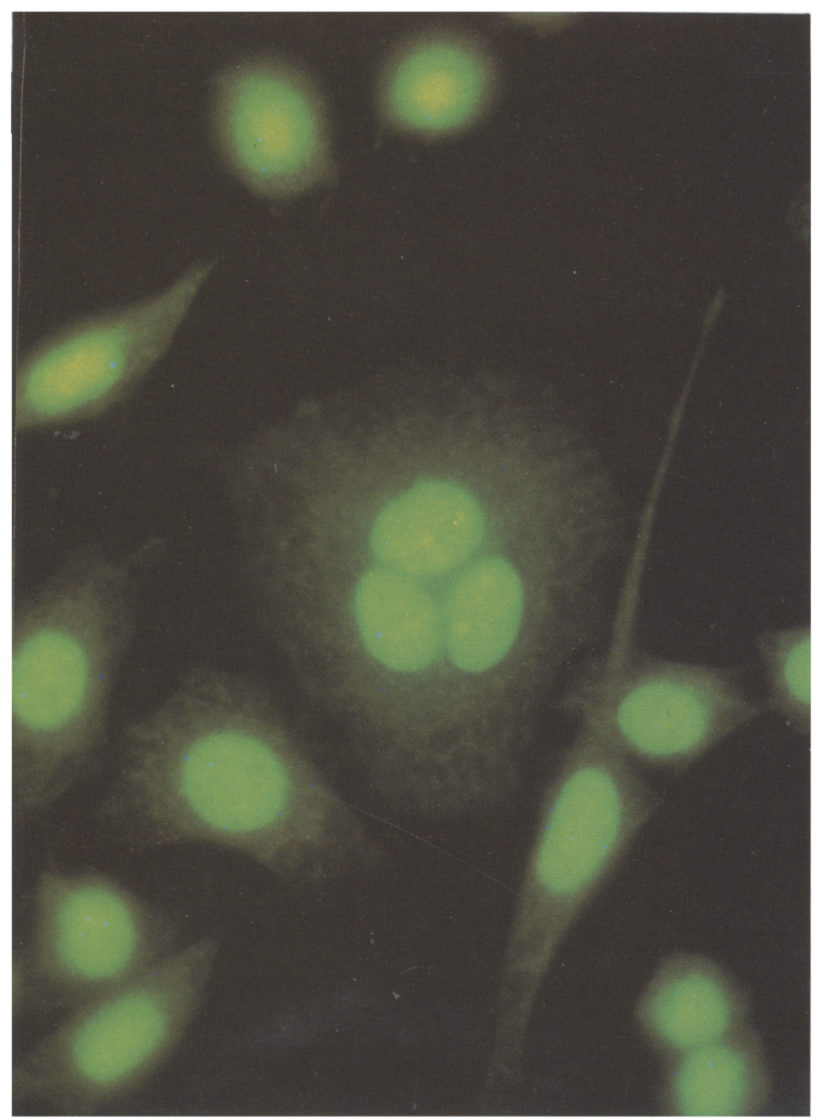

clearly nuclear localized, in agreement with the biochemical fractionation data of Figure 1. We note that the RING3 ORF contains a putative nuclear localization signal (NLS) (see Fig. 4B).
Figure 5. Immunoblot, immunoprecipitation, and immunofluorescence. $(A)$ Immunoblot analysis. HeLa nuclear extract was resolved by SDS-PAGE, transferred to nitrocellulose, and immunoblotted with rabbit preimmune serum or purified $\alpha$ RING3 antibody. $(B)$ Immunoprecipitation analysis. HeLa nuclear extract was immunoprecipitated with rabbit preimmune serum (1:50) or $\alpha$ RING3 antibody $(1: 50)$ by recombinant protein A-agarose. The immune complexes were resolved by SDSPAGE and assayed for renaturable autophosphorylation activity as in Fig. 1. (C) Nuclear immunofluorescence of $\alpha$ RING3. HeLa cells were fixed and incubated with $\alpha$ RING 3 antibody. Primary antibody was visualized with FITC conjugated to goat antirabbit secondary antibody. $\alpha$ RING3 immunofluorescence colocalized with 4',6-diamidino-2-phenylindole (DAPI) stain and with immunofluorescence from rabbit antibody to TATA box-binding protein $(\alpha \mathrm{TBP})$, both of which are authentically nuclear (data not shown|. Rabbit preimmune serum did not exhibit significant immunofluorescence (data not shown).

\section{Recombinant RING3 has kinase activity}

We then asked whether expression of RING3 cDNA in bacteria and mammalian cells gave rise to a protein with kinase activity. For bacterial expression, RING3 was tagged with six histidines at the amino terminus, expressed in Escherichia coli. and purified to homogeneity by $\mathrm{Ni}^{+}$-agarose chromatography (Fig. 6A; B, Coomassie, WT). Figure 6B (lane 2) shows that this E. coli-derived protein lacked kinase activity. In several other cases, recombinant kinases are inactive in the absence of specific post-translational phosphorylation (e.g., see Williams et al. 1992; Kozma et al. 1993). Therefore, we incubated the E. coli-derived RING3 with HeLa nuclear extract and ATP and repurified it according to the scheme shown in Figure 6A, which included a stringent $6 \mathrm{~m}$ guanidine hydrochloride wash of the $\mathrm{Ni}^{+}$column to remove any contaminating kinase activities (see Fig. 6B, lanes 1,8). The modified recombinant protein now possessed kinase activity (Fig. 6B, lane 3); as expected, this modification was ATP dependent (Fig. 6B, lane 8). These results also imply the existence of a RING3-activating kinase in HeLa nuclear extract.

To provide further evidence that the observed kinase activity was from recombinant RING3, we constructed two RING3 carboxy-terminal deletion mutants (Fig. 6B, bottom). The first deletion removed a polyserine tail (see Fig. 4B), which slightly reduced its size (Fig. 6B, Coomassie, $\Delta$ SnaBI), but did not abolish kinase activity (Fig. 6B, lane 5). The reduced size of the autophosphorylation activity observed with the $\Delta$ SnaBI mutant strongly argues that recombinant RING3 is the kinase. (Like wild-type RING3, the unmodified $\triangle$ SnaBI protein lacked kinase activity; Fig. 6B, lane 4.) A more extensive deletion $(\triangle B s p M I)$, which removed a putative catalytic glutamate (see below), abolished kinase activity (Fig. 6B, lane 6).

To confirm that recombinant RING3 possessed the same specificity as the HeLa $90-\mathrm{kD}$ nuclear kinase, we compared the ability of the two enzymes to phosphorylate peptide substrates. Table 1 shows that, like the HeLa 
A

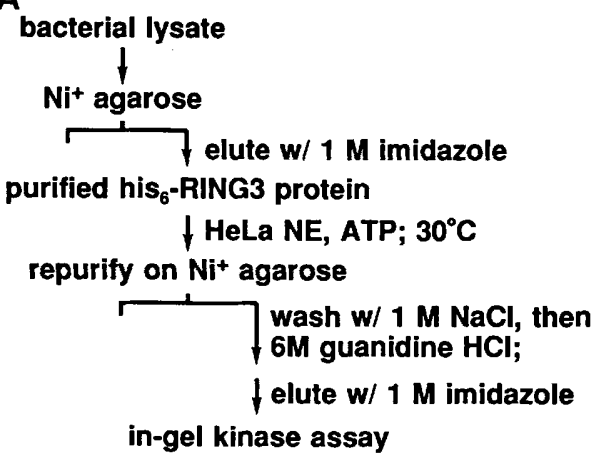

B

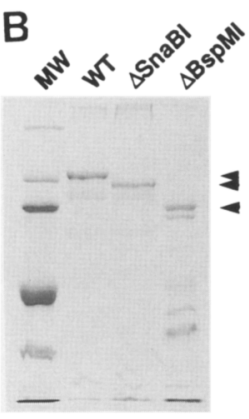

Coomassie

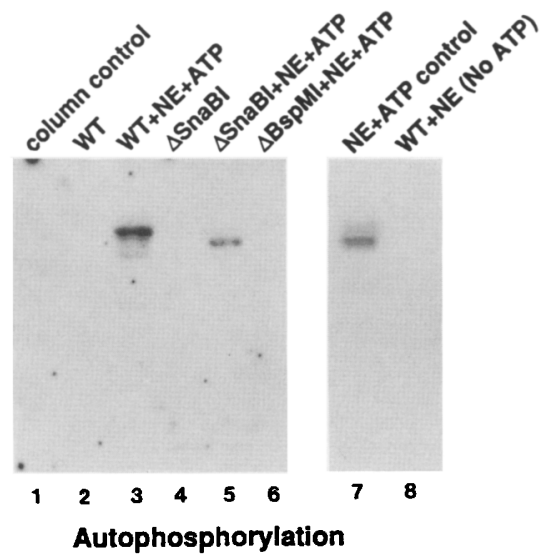

WT

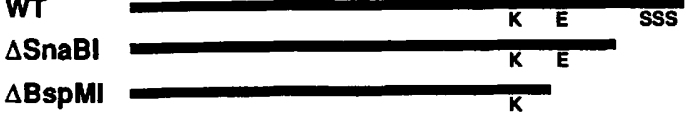

Figure 6. Autophosphorylation activity of recombinant wild-type and mutant RING3 derivatives. (A) Purification of recombinant RING3. (B) Activity of recombinant RING3. Bacterially expressed wild type (WT) and two deletion mutants ( $\triangle$ SnaBI and $\Delta B$ spMI) of histidine-tagged RING3 were visualized by Coomassie stain and assayed by in-gel kinase assay. (Lane 1) NE incubated with ATP in the absence of recombinant enzyme, then processed $(A)$ as a negative control (column control); (lane 2) unmodified WT enzyme; (lane 3) WT enzyme after modification with NE and ATP; (lane 4) unmodified $\Delta$ SnaBI enzyme; (lane 5) $\Delta$ SnaBI enzyme after modification; (lane 6) $\triangle B s p M I$ enzyme after modification; (lane 7) positive control for NE alone; (lane 8) WT enzyme after modification with NE in the absence of ATP.

90-kD nuclear kinase, RING3 phosphorylated only peptide substrates for both cAMP-dependent protein kinase (Kemptide) and smooth muscle myosin light-chain kinase. Finally, we used site-directed mutagenesis to change a putative catalytic lysine (see below) to alanine (K578A). When expressed as a histidine-tagged protein and modified as above, this RING3 amino acid substitution mutant was unable to phosphorylate any of these peptides (Table 1).

For mammalian overexpression, COS cells were transiently transfected with a CMV vector that directed expression of RING3 cDNA (CMV-RING3). Nuclear extracts were prepared from these transfected cells and fractionated by phosphocellulose chromatography, which we found could resolve ectopically expressed from endogenous kinase activity (Fig. 7; data not shown). Figure 7 shows that $90-\mathrm{kD}$ nuclear kinase activity was greatly increased in COS cells transfected with CMVRING3. These data and those of Figures 5, B and C, 6B, and Table 1 indicate that RING3 is a nuclear kinase.

\section{Potential relevance to leukemia}

The stimulation of 90-kD autophosphorylation activity by serum (Fig. 3A) and mitogenic lectins (Fig. 3B) suggested a relationship with cellular proliferation. Furthermore, as discussed below, several pieces of evidence suggested that RING3 may be in a signal transduction pathway involved in human leukemias. To test whether there is an association between $90-\mathrm{kD}$ kinase activity and leukemic proliferation, PBLs from normal individuals were compared with an equivalent number of PBLs from individuals with chronic lymphocytic leukemia
(CLL) or acute lymphocytic leukemia (ALL). Figure 8A shows that leukemic PBLs (blasts or mature T cells) had very high levels of $90-\mathrm{kD}$ autophosphorylation activity

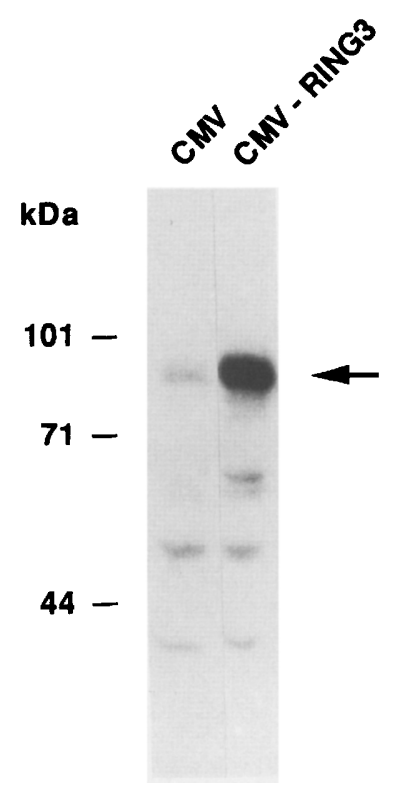

Figure 7. Mammalian expression of 90-kD nuclear kinase activity from RING3 cDNA. COS cells were transfected by calcium phosphate and harvested $48 \mathrm{hr}$ later. Nuclear extracts were applied to phosphocellulose and eluted with $0.2 \mathrm{M} \mathrm{NaCl}$, which separated ectopically expressed activity from endogenous activity. Transfections were with empty vector (CMV) or with vector containing RING3 cDNA (CMV-RING3). An arrow indicates the $90-\mathrm{kD}$ multiplet. 


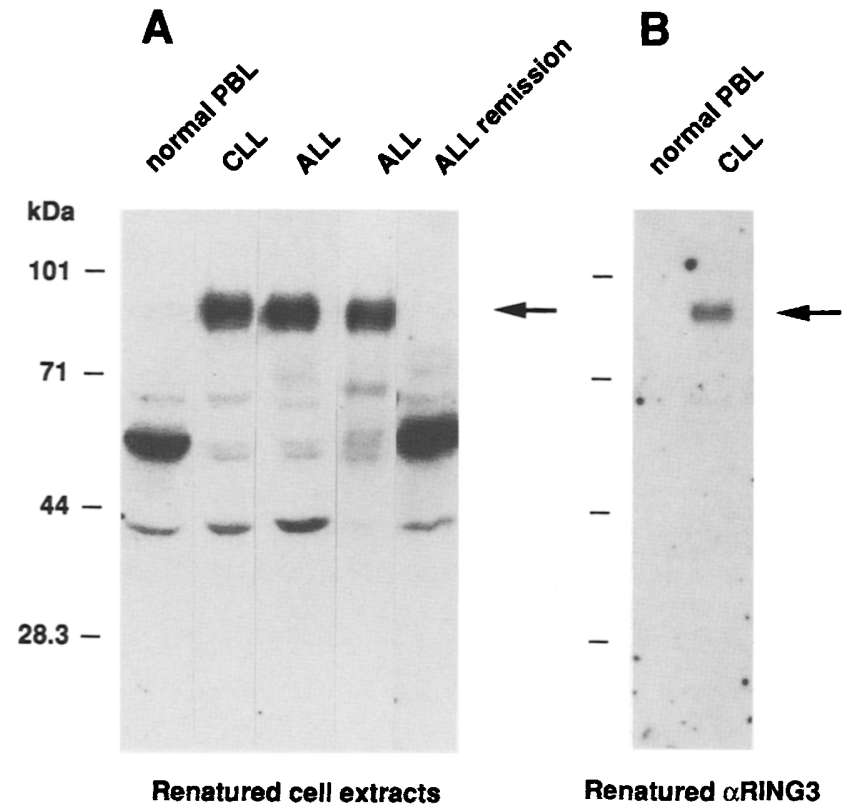

Renatured $\alpha$ RING3
immune complexes

Figure 8. Elevated $90-\mathrm{kD}$ nuclear kinase activity in acute and chronic leukemic cells. $(A)$ Cell extracts were prepared from $10^{7}$ PBLs. Proteins were separated by SDS-PAGE, renatured, and autophosphorylated. (Normal PBL) Normal 34-year-old male; (CLL) 69-year-old male diagnosed with chronic lymphocytic leukemia ( $>10^{6}$ mature $\mathrm{T}$ cells $/ \mu \mathrm{l}$, lymphostasis, immune suppression); (ALL) 4-year-old female diagnosed with acute lymphocytic leukemia in proliferative blast stage (ALL) 15-year-old male with same diagnosis; (ALL remission) same 15-year-old male after chemotherapy. Results were representative for 10 normal controls and $10 \mathrm{ALL}$ patients $1>5 \times 10^{4} \mathrm{blasts} / \mu \mathrm{l}$ in each case). Immunoblot with $\alpha$ RING 3 confirmed no significant differences in $90-\mathrm{kD}$ protein expression between ALL cases and controls (results not shown). (B) Two PBL extracts from $A$ were immunoprecipitated with $\alpha$ RING3 antibody. Immune complexes were washed, solubilized with SDS, and assayed as in $A$. The $90-\mathrm{kD}$ kinase activity is indicated by an arrow.

compared with normal PBLs. Interestingly, there was a renaturable autophosphorylation activity of $\sim 50 \mathrm{kD}$ that was prominent only in normal PBLs. One of the ALL patients entered remission after chemotherapy, and the same number of PBLs were assayed again. In this case (ALL remission), the $90-\mathrm{kD}$ autophosphorylation signal was comparable with normal controls.

To confirm that the increased $90-\mathrm{kD}$ autophosphorylation activity in leukemic cells was related to RING3, we performed an immunoprecipitation experiment. aRING3 immune complexes were resolved by SDSPAGE and assayed by renaturation and autophosphorylation. Autophosphorylation $(90 \mathrm{kD})$ was recovered only from leukemic PBLs (Fig. 8B). Taken together, these data reveal a correlation between $90-\mathrm{kD}$ autophosphorylation activity and leukemia.

\section{Discussion}

We sought to identify nuclear kinases that might be important in signal transduction and growth control. We found a novel, renaturable kinase of an apparent molecular mass of $90 \mathrm{kD}$. Three lines of evidence indicate that the kinase is encoded by human gene RING3: First, two microsequenced peptides of the purified $90-\mathrm{kD}$ nuclear kinase matched RING3 in the GenBank data base (Fig. 4B); second, antibody raised against recombinant RING3 specifically immunoprecipitated the $90-\mathrm{kD}$ nuclear kinase (Fig. 5B); and third, RING3 cDNA encoded 90-kD autophosphorylation and transphosphorylation activities with properties similar to the native enzyme (Figs. 6B and 7; Table 1).

\section{RING3 is a nonconsensus kinase}

Tryptic peptides of the purified kinase were highly homologous to two proteins that share regions of homology: fsh and RING3. While this manuscript was in preparation, we reprobed the GenBank data base with the two peptide sequences and found a new match to an unpublished open reading frame, accession number D26362, that is highly homologous to RING3. These results suggest that the $90-\mathrm{kD}$ kinase may be part of a protein family. There was no prior information regarding the cellular localization, biochemical activity, or expression of these proteins. For convenience of discussion, we will refer to the mammalian proteins as "RING3 kinase." The homologous regions of fsh, RING3, and D26362 include kinase motifs (see below), bromodomains (found in certain regulatory genes; Haynes et al. 1992; Tamkun et al. 1992), and PEST sequences (linked to high turnover rates; Dice 1987; Rechsteiner et al. 1987; Rechsteiner 1988, 1990; Chevaillier 1993) (Fig. 4B).

Most protein kinases conform to a consensus comprising a set of relatively short amino acid motifs (Hunter 1987). RING3 and fsh appear to deviate from this consensus, which explains in part why these proteins were not previously suspected to be kinases. Whereas certain kinases, for example, p160 ${ }^{\mathrm{c}-\mathrm{BCR}}$ (Maru and Witte 1991) lack the canonical serine/threonine sequence motifs, careful inspection of RING3 reveals the presence of consensus kinase motifs that appear to be "out of order" (Fig. 9). For example, RING3 contains a putative ATP binding motif (GXGXXG; subdomain I; Hanks et al. 1988; Hanks 1991) at amino acid 558 and a putative catalytic lysine (AXK; subdomain II) at amino acid 578 (Figure 9). When compared with a data base of all kinases, these sequences and spacing are most similar to the corresponding subdomains of $\mathrm{c}-$ mos. A putative subdomain III, which contains a catalytic glutamate at amino acid 605 , is not closely related to c-mos but falls into a different class of kinases characterized by an EKR motif at that position. Therefore, RING3 is not a close relative of any existing protein kinase. Other putative subdomains, for example, kinase consensus sequences YHRDLK (subdomain VIB) and APE (subdomain VIII) (Hanks et al. 1988; Hanks 1991), are found in the expected order in two amino-terminal domains of both RING3 and fsh. Kinases with multiple catalytic domains (Jones et al. 1988; Banerjee et al. 1990) or mosaics of serine/threonine and tyrosine kinase subdomains (Levin et al. 1987) 
have been described. We conclude that RING3 defines a new class of kinase, possessing several serine/threonine kinase motifs, but with rearranged subdomains.

There are several precedents for enzymes with "scrambled" primary sequence motifs. For example, lipases, serine proteases, and cholinesterases employ a similar

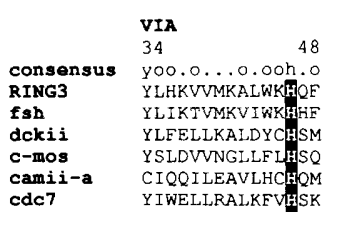

consensus
RING3
fsh
ecapk
tpk1
pkc-z
stk
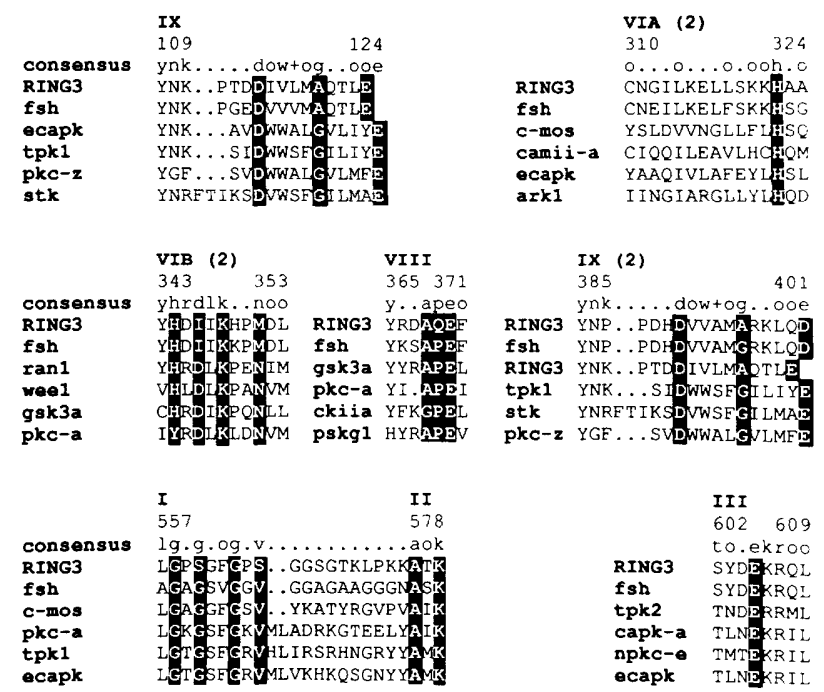
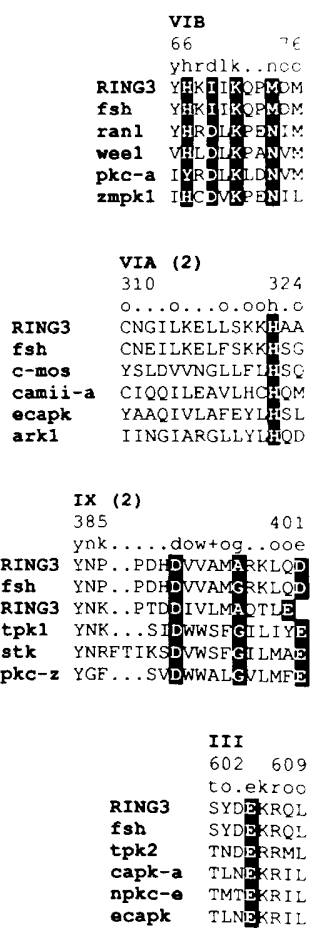

Figure 9. Comparison of putative subdomains of RING3 and fsh with known protein kinases. The authentic subdomains of known kinases are compared with fsh and RING3; the closest overall resemblances were with kinases of the cAMP-dependent protein kinase and protein kinase $\mathrm{C}$ families. For comparison, some kinases with unusual subdomain sequences are included. Numbering corresponds to the translated RING3 cDNA sequence. Conserved amino acids are identified above the RING3 sequence by lowercase letter. The most highly conserved amino acids are identified by a solid black box with white type. Hydrophobic amino acids $(F, Y, L, V, W)$ are referred to as a class with an o, small side chain $(A, S, T)$ with a + , and no consensus with a period. Where RING3 appears twice, internally duplicated domains are compared. The Hanks subdomains that are not obviously present in RING3 are IV, V, VII, and the conserved arginine of XI. (ark1) Arabidopsis thaliana receptor kinase; (camii-a) rat calcium/calmodulin-dependent protein kinase II- $\alpha$; (capk-a) human cAMP-dependent protein kinase $\alpha$; (cdc7) Saccharomyces cerevisiae wild-type CDC7; (ckiia) human casein kinase II- $\alpha_{;}$(c-mos) human cellular homolog of v-mos; (dckii) Drosophila melanogaster casein kinase II- $\alpha$; (ecapk) Caenorhabditis elegans cAMP-dependent protein ki-

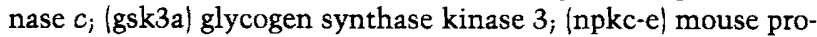
tein kinase C-like protein; (pkc-a) rat protein kinase $C-\alpha ;(p k c-z)$ rat protein kinase $\mathrm{C}-\zeta_{;}$(pskgl) human putative protein-serine kinase; (ranl) Schizosaccharomyces pombe wild-type "meiotic bypass" protein; (stk) hydra src-related protein; (tpk1) S. cerevisiae cAMP-dependent protein kinase type $1 ;($ tpk2) S. cerevisiae cAMP-dependent protein kinase type 2 ; (weel) S. pombe wildtype "reduced size at division" protein; (zmpkl) maize receptor protein kinase. catalytic triad of serine, histidine, and aspartate/glutamate in a conserved three-dimensional arrangement, but the individual members of the triad can be located on different loops or even on $\alpha$-carbon backbones of opposite direction (Schrag et al. 1991; Dodson et al. 1992).

\section{Role of RING3 in development and leukemogenesis}

The physiological substrates of RING3 kinase are unknown, but in light of its nuclear location and responsiveness to mitogenic signals, transcription factors are likely targets. Sequence homology strongly suggests that fsh, a Drosophila homeotic gene product that is highly related to RING3, is also a kinase (Figs. 4B and 9). Genetic studies in Drosophila suggest that $f s h$ is a transacting effector of trithorax, another homeotic gene (Digan et al. 1986; Mozer and Dawid 1989; Breen and Harte 1991, 1993). For example, reduced levels of $f s h$ can increase the severity of trithorax mutations (Gans et al. 1980; Forquignon 1981). The sequence of trithorax strongly suggests that it is a transcription factor (Mazo et al. 1990). On the basis of these considerations, we hypothesize that fsh activates trithorax through phosphorylation, and that these two proteins are components of a signal transduction pathway involved in Drosophila development.

A human homolog of trithorax has been identified and referred to as ALL-1 lalso called HRX, MLL, and HTRX1; Cimino et al. 1991; Djabali et al. 1992; Gu et al. 1992; Tkachuk et al. 1992; Ford et al. 1993). In certain leukemias, the gene encoding ALL-1 is interrupted by a reciprocal chromosomal translocation that results in an ALL-1 fusion protein, whose functional properties are presumably altered. In several other instances, human homologs of Drosophila homeotic genes are rearranged in leukemic cells: An 8q22 translocation associated with acute myelogenous leukemia interrupts a gene with homology to runt (Miyoshi et al. 1993), an 11q23 translocation associated with acute promyelogenous leukemia involves a gene with a Krüppel-like zinc finger /Chen et al. 1993), and an 11q23 translocation associated with T-lymphoblastic leukemia interrupts TAN-1, a human homolog of notch (Ellisen et al. 1991).

Intriguingly, our results have revealed a relationship between RING3 kinase activity and lymphocytic leukemia. These new data, in conjunction with previous studies on ALL-1, suggest that RING3 and ALL-1 are components of a signal transduction pathway that becomes deregulated in certain leukemias. The availability, for the first time, of an assayable biochemical activity for a component of this putative signal transduction pathway will facilitate more detailed study. Further analysis of the functional relationship between fsh and trithorax and between RING3 and ALL-1 will help illuminate the role of nuclear kinase activity in development, growth control, and leukemogenesis.

\section{Materials and methods}

\section{Autophosphorylation assay}

Extracts were prepared (Dignam et al. 1983) in the presence of 
sodium vanadate $(1 \mathrm{~mm})$ and $\beta$-glycerolphosphate $(50 \mathrm{~mm})$ and centrifuged $\left(100,000 \mathrm{~g}, 60 \mathrm{~min}\right.$ at $\left.4^{\circ} \mathrm{C}\right)$ to remove particulate matter. The proteins in the supernatants were separated by SDSPAGE (Laemmli 1970), electroblotted to nitrocellulose or polyvinyldifluoride membranes, denatured, renatured, probed with $\left[\gamma^{32} \mathrm{P}\right]$ ATP for autophosphorylation (Ferrell and Martin 1989), and subjected to autoradiography.

\section{In vitro phosphorylation}

Synthetic peptides were incubated at $30^{\circ} \mathrm{C}$ for $1 \mathrm{hr}$ in $10-\mu \mathrm{l}$ reactions containing $30 \mathrm{mM} \mathrm{MgCl}_{2}, 30 \mathrm{mM}$ HEPES ( $\mathrm{pH} 8.0$ ), 2 mM DTT, $0.5 \mathrm{~mm}$ EDTA, 0.1\% NP-40, $10 \mu \mathrm{M}$ ATP, $0.15 \mathrm{mCi} /$ $\mathrm{ml}$ of $\left[\gamma^{32} \mathrm{P}\right] \mathrm{ATP}$, and $1 \mathrm{mg} / \mathrm{ml}$ of peptide. Reaction mixtures were quenched with ice-cold $10 \%$ phosphoric acid and applied to $0.1-\mathrm{ml}$ phosphocellulose columns or $\mathrm{P}-81$ paper circles (Whatman), which were washed extensively with $0.5 \%$ phosphoric acid. Incorporation of ${ }^{32} \mathrm{P}$ into peptide $(\sim 100,000 \mathrm{dpm}$ for Kemptide/ was determined for duplicate reactions by Cerenkov counting. (Raytide and $\mathrm{p} 43^{\mathrm{v}-a b l}$ were from Oncogene Science.) For MBP phosphorylation, reactions contained $1 \mathrm{mg} / \mathrm{ml}$ of protein and were quenched with SDS sample buffer. Radiolabeled MBP was resolved by PAGE and visualized by autoradiography. Phosphoaminoacids were determined (Cooper et al. 1983; Lewis et al. 1990).

\section{Kinase purification}

HeLa nuclear extract $(100 \mathrm{ml})$ was applied to a column of reactive green-19 resin $140-\mathrm{ml}$ bed volume, equilibrated with buffer A $(20 \mathrm{~mm}$ Tris at $\mathrm{pH} 7.0,50 \mathrm{~mm} \mathrm{NaCl}, 50 \mathrm{~mm} \beta$-glycerolphosphate, $10 \%$ glycerol, $1 \mathrm{~mm}$ Na vanadate, $1 \mathrm{~mm}$ DTT, $0.2 \mathrm{~mm}$ EDTA, $0.02 \% \mathrm{NaN}_{3}$, and $0.1 \% \mathrm{NP}-40$ ). All steps were conducted on ice or at $4^{\circ} \mathrm{C}$. The flowthrough was discarded, and the column was washed extensively with buffer $A$ and then eluted in batch with buffer B (buffer A supplemented with $20 \mathrm{~mm}$ disodium ATP, $20 \mathrm{~mm}$ EDTA, and $0.5 \mathrm{M} \mathrm{NaCl}$, at pH 7.0). Ammonium sulfate was gradually added to the eluate to $50 \%$ (wt/ vol) over $60 \mathrm{~min}$ at $4^{\circ} \mathrm{C}$, whereupon the suspension was centrifuged $\left(10,000 \mathrm{~g}, 45 \mathrm{~min}\right.$ at $\left.4^{\circ} \mathrm{C}\right)$. The pellet was recovered, dissolved in buffer $\mathrm{C}$ (buffer A supplemented with $10 \mathrm{~mm}$ $\mathrm{MnCl}_{2}, \mathrm{pH}$ 8.0), and desalted on Sephadex G-25 that had been equilibrated with buffer $\mathrm{C}$. The desalted protein was applied to a column of Cibacron blue 3GA agarose (type 3000) that had been equilibrated with buffer $C$. The flowthrough was discarded; the column was washed extensively with buffer $C$ and eluted in batch with buffer $\mathrm{D}$ (buffer A supplemented with 20 mM EDTA and $0.15 \mathrm{M} \mathrm{NaCl}$, at $\mathrm{pH} 8.0$ ). The eluate was diluted $1: 1$ with buffer $\mathrm{E}$ (buffer $\mathrm{A}$ with no $\mathrm{NaCl}$, at $\mathrm{pH} 8.0$ ) and applied to phosphocellulose that had been equilibrated with buffer $F$ (buffer A at $\mathrm{pH}$ 8.0). The phosphocellulose was washed extensively and eluted in batch with $0.6 \mathrm{M} \mathrm{NaCl}$ in buffer $\mathrm{F}$. The eluate was precipitated with trichloroacetic acid (10\% final), washed with acetone, and solubilized in SDS sample buffer. Proteins were resolved by SDS-PAGE in $8 \%$ polyacrylamide, blotted to nitrocellulose, and visualized with Ponceau S. The band corresponding to the autophosphorylation activity of the $90-\mathrm{kD}$ kinase was excised and digested with trypsin. Tryptic peptides were resolved by HPLC and microsequenced.

\section{Plasmid constructs and antibody production}

RING3 cDNA (clone CEM32, a 4-kb insert in CDM8; Beck et al. 1992) was propagated in MC1061/P3 (Invitrogen). A 1426-bp NcoI-EcoRI fragment (nucleotides 2214-3640) of RING3 was ligated into pGEX-2T for bacterial overexpression ( $\mathrm{Lin}$ and
Green 1991|. Rabbit polyclonal antibody was raised against purified glutathionine $S$-transferase (GST) fusion protein. For production of purified antibody, rabbit immune sera were incubated with GST-agarose to remove antibodies against GST epitopes. Polyclonal antibodies against RING3 epitopes were then purified by antigen affinity chromatography on Affigel columns that contained the purified GST fusion protein.

For construction of a eukaryotic overexpression vector, the full-length RING3 coding sequence was obtained by doublestranded polymerase chain reaction (PCR) amplification of clone CEM32 with a forward primer $15^{\circ}$-CGCCGCGGATCCATGGCTTCGGTGCCTGCT-3') that engineered a 5' BamHI site at the amino-terminal methionine of the coding sequence (nucleotide 1178 ) and a reverse primer (5'-GGCTGGGAATTCAATGTT-3') that was complementary to the native EcoRI site in the $3^{\prime}$-untranslated region (nucleotide 3640). The 2467-bp BamHI-EcoRI fragment from PCR was ligated into pcDNA(I) (Invitrogen). For bacterial overexpression, this fragment was ligated into RSETA (Invitrogen), which fused six histidines to the amino terminus of RING3.

\section{Deletion mutants and site-directed mutagenesis}

Deletion mutants of RING3 were constructed as follows: a 481bp $S n a \mathrm{BI}-E c o$ RI fragment that encodes a polyserine tail was removed from the carboxyl terminus (nucleotides 3156-3640, $\Delta$ SnaBI) . A 597-bp internal BspMI-BspMI fragment that encodes a putative catalytic glutamate (nucleotide $2972, \mathrm{E} 605$ ) in addition to the polyserine tail (nucleotides 2914-3505, $\Delta$ BspMI) was removed. Overhanging ends were then filled-in with DNA polymerase I (Klenow), and the vector was religated blunt.

A site-directed mutant of RING3 was constructed from a 1508-bp SphI-EcoRI fragment (nucleotides 2128-3640) that contains the codon for a putative catalytic lysine (nucleotide $2897, \mathrm{~K} 578$ ). This fragment was subcloned into M13 mp18 and mutagenized (Kunkel 1985) with an oligonucleotide, 5'-CCCAAAAAGGCCACAGCGACGGCCCCACCTGCC-3', where GCG (alanine) replaced AAG (lysine) and ACG is a silent site replacement of ACC. A 391-bp EspI-EspI fragment (nucleotides 2592-2983) of the M13 RF DNA was used to shuttle the mutated site (K578A) back into RSETA for overexpression of the full-length mutant protein. All clones were verified by dideoxy sequencing.

\section{HeLa NE modification of RING3}

Histidine-tagged recombinant protein was purified on $\mathrm{Ni}^{+}$-agarose (Qiagen), and phosphorylated by incubation for $30 \mathrm{~min}$ at $30^{\circ} \mathrm{C}$ with HeLa nuclear extract in buffer A that contained 10 mM ATP, $5 \mathrm{~mm} \mathrm{MgCl}_{2}$, and protease inhibitors but no Na vanadate. As a negative control for ATP-dependent modification, $\mathrm{HeLa} \mathrm{NE}$ was incubated with $460 \mathrm{U} / \mathrm{ml}$ of hexokinase and 250 $\mathrm{mM} \mathrm{D}$-glucose $\left(25^{\circ} \mathrm{C}\right.$ for $\left.30 \mathrm{~min}\right)$ to deplete ATP before recombinant protein was added. Phosphorylated protein was repurified on $\mathrm{Ni}^{+}$-agarose and assayed by in-gel kinase assay (Gotoh et al. 1990).

\section{Sequence analysis}

Sequence data bases were scanned with BLAST (Altschul et al. 1993) and Intelligenetics software. Putative subdomains of RING3 and fsh were aligned to a data base of the catalytic domains of all known protein kinases (quinn@salk-sc2.sdsc.edu). Separate alignments were performed for each subdomain and were optimized by visual inspection. 


\section{Acknowledgments}

We thank Stephan Beck for RING3 cDNA, Bob Choy for rabbit antibody to TBP, Benoit Dérijard for help with IL-1 experiments, Joel Greenberger for 32D cells, Robin Heller-Harrison for 3T3L1 cells, Jes Klarlund for help with peptide phosphorylation experiments, William Lane of the Microchemistry Facility at Harvard University for microsequencing, and Robert Singer for immunofluorescence facilities. For leukemic PBLs, we thank Peter Newburger of the University of Massachusetts Medical Center and Steven Sallan of Dana Farber Cancer Institute. We thank Michael Czech, Roger Davis, Tony Ip, Hyockman Kwon, Joe Reese, Juan Valcarcel, Greg Viglianti, and Phil Zamore for comments on the manuscript. We thank Terri O'Toole for excellent secretarial assistance.

The publication costs of this article were defrayed in part by payment of page charges. This article must therefore be hereby marked "advertisement" in accordance with 18 USC section 1734 solely to indicate this fact.

\section{References}

Altschul, S.F., W. Gish, W. Miller, E.W. Myers, and D.J. Lipman. 1993. Basic local alignment tool. J. Mol. Biol. 215: 403-410.

Baeuerle, P.A. and D. Baltimore. 1988a. Activation of DNAbinding activity in an apparently cytoplasmic precursor of the NF-kB transcription factor. Cell 53: 211-217.

- 1988b. IкB: A specific inhibitor of the NF- $\mathrm{kB}$ transcription factor. Science 242: 540-546.

Baneriee, P., M.F. Ahmad, J.R. Grove, C. Kozlosky, D.J. Price, and J. Avruch. 1990. Molecular structure of a major insulin/ mitogen-activated $70-\mathrm{kDa}$ S6 protein kinase. Proc. Natl. Acad. Sci. 87: 8550-8554.

Beck, S., I. Hanson, A. Kelly, D.J.C. Pappin, and J. Trowsdale. 1992. A homologue of the Drosophila female sterile homeotic (fsh) gene in the class II region of the human MHC. DNA Seq. 2: 203-210.

Breen, T.R. and P.J. Harte. 1991. Molecular characterization of the trithorax gene, a positive regulator of homeotic gene expression in Drosophila. Mech. Dev. 354: 113-127.

. 1993. Trithorax regulates multiple homeotic genes in the bithorax and Antennapedia complexes and exerts different tissue-specific, parasegment-specific and promoter-specific effects on each. Development 117: 119-134.

Chen, R.-H., C. Sarnecki, and J. Blenis. 1992. Nuclear localization and regulation of $e r k$ - and rsk-encoded protein kinases. Mol. Cell. Biol. 12: 915-927.

Chen, Z., N.J. Brand, A. Chen, S.-J. Chen, J.-H. Tong, Z.-Y. Wang, S. Waxman, and A. Zelent. 1993. Fusion between a novel Krüppel-like zinc finger gene and the retinoic acid receptor $\alpha$-locus due to a variant $t(11 ; 17)$ translocation associated with acute promyelocytic leukemia. $E M B O /$. 12: 11611167.

Chevaillier, P. 1993. PEST sequences in nuclear proteins. Int. J. Biochem. 25: 479-482.

Chida, K. and P.K. Vogt. 1992. Nuclear translocation of viral Jun but not of cellular Jun is cell cycle dependent. Proc. Natl. Acad. Sci. 89: 4290-4294.

Cimino, G., D.T. Moir, O. Canaani, K. Williams, W.M. Crist, S. Katzav, L. Cannizzaro, B. Lange, P.C. Nowell, C.M. Croce, and E. Canaani. 1991. Cloning of ALL-1, the locus involved in leukaemias with the $t(4 ; 11)(q 21 ; q 23)$, and $t(11 ; 19)(q 23: p 1)$ chromosome translocations. Cancer Res. 51: 6712-6714.

Cooper, J.A., B.M. Sefton, and T. Hunter. 1983. Detection and quantification of phosphotyrosine in proteins. Methods Enzymol. 99: 387-402.
Darnell, J.E., Jr., I.M. Kerr, and G.A. Stark. 1994. Jak-STAT pathways and transcriptional activation in response to IFNs and other extracellular signalling proteins. Science 264: 14151421.

Devoto, S.H., M. Mudryj, J. Pines, T. Hunter, and J.R. Nevins. 1992. A cyclin A-protein kinase complex possesses sequence-specific DNA binding activity: p33 $3^{\text {cdk2 }}$ is a component of the E2F-cyclin A complex. Cell 68: 167-176.

Dice, J.F. 1987. Molecular determinants of protein half-lives in eukaryotic cells. FASEB I. 1: 349-357.

Digan, M.E., S.R. Haynes, B.A. Mozer, I.B. Dawid, F. Forquignon, and M. Gans. 1986. Genetic and molecular analysis of fs(1)h, a maternal effect homeotic gene in Drosophila. Dev. Biol. 114: 161-169.

Dignam, J.D., R.M. Lebovitz, and R.G. Roeder. 1983. Accurate transcription by RNA polymerase II in a soluble extract from isolated mammalian nuclei. Nucleic Acids Res. 11: 14751489.

Djabali, M., L. Selleri, P. Parry, M. Bower, B.D. Young, and G.A. Evans. 1992. A trithorax-like gene is interrupted by chromosome 1lq23 translocations in acute leukemias. Nature Genet. 2: 113-118.

Dodson, G.G., D.M. Lawson, and F.K. Winkler. 1992. Structural and evolutionary relationships in lipase mechanism and activation. Faraday Discuss. 93: 95-105.

Ellisen, L.W., J. Bird, D.C. West, A.L. Soreng, T.C. Reynolds, S.D. Smith, and J. Sklar. 1991. TAN-1, the human homolog of the Drosophila notch gene, is broken by chromosomal translocations in T-lymphoblastic neoplasms. Cell 66: 649-661.

Faha, B., M.E. Ewen, L.-H. Tsai, D.M. Livingston, and E. Harlow. 1992. Interaction between human cyclin A and adenovirus E1A-associated pl07 protein. Science 255: 87-90.

Feaver, W.J., O. Gileadi, Y. Li, and R. Kornberg. 1991. CTD kinase associated with yeast RNA polymerase II initiation factor b. Cell 67: 1223-1230.

Ferrell, J.E., Ir. and G.S. Martin. 1989. Thrombin stimulates the activities of multiple previously unidentified protein kinases in platelets. J. Biol. Chem. 264: 20723-20729.

Finnie, N., T. Gottleib, K. Hartley, and S.P. Jackson. 1993. Transcription factor phosphorylation by the DNA-dependent protein kinase. Biochem. Soc. Trans. 21: 930-935.

Ford, A.M., S.A. Ridge, M.E. Cabrera, H. Mahmoud, C.M. Steel, L.C. Chan, and M. Greaves. 1993. In utero rearrangements in the trithorax-related oncogene in infant leukemias. Nature 363: 358-360.

Forquignon, F. 1981. A maternal effect mutation leading to deficiencies of organs and homeotic transformations in the adults of Drosophila. Wilhelm Roux's Arch. Dev. Biol. 190: 132-138.

Gans, M., F. Forquignon, and M. Masson. 1980. The role of dosage of the region 7D1-7D5-6 of the X chromosome in the production of homeotic transformations in Drosophila melanogaster. Genetics 96: 887-902.

Gotoh, Y., E. Nishida, T. Yamashita, M. Hoshi, M. Kawakami, and H. Sakai. 1990. Microtubule-associated-protein (MAP) kinase activated by nerve growth factor and epidermal growth factor in PC12 cells. Identity with the mitogen-activated MAP kinase of fibroblastic cells. Eur. J. Biochem. 193: 661-669.

Gu, Y., T. Nakamura, H. Alder, R. Prasad, O. Canaani, G. Cimino, C.M. Croce, and E. Canaani. 1992. The $t(4 ; 11)$ chromosome translocation of human acute leukemias fuses the ALL-1 gene, related to Drosophila trithorax, to the AF-4 gene. Cell 71: 701-708.

Hanks, S.K. 1991. Eukaryotic protein kinases. Curr. Biol. 1: 369-383. 
Hanks, S.K., A.M. Quinn, and T. Hunter. 1988. The protein kinase family: Conserved features and deduced phylogeny of the catalytic domains. Science 241: 42-52.

Haynes, S.R., B.A. Mozer, N. Bhatia-Dey, and I.B. Dawid. 1989. The Drosophila fsh locus, a maternal effect homeotic gene, encodes apparent membrane proteins. Dev. Biol. 134: 246257.

Haynes, S.R., C. Dollard, F. Winston, S. Beck, J. Trowsdale, and I. Dawid. 1992. The bromodomain: A conserved sequence found in human, Drosophila and yeast proteins. Nucleic Acids Res. 20: 2603.

Hunter, T. 1987. A thousand and one protein kinases. Cell 50: $823-829$.

Hunter, T. and M. Karin. 1992. The regulation of transcription by phosphorylation. Cell 70: 375-387.

Jackson, S.P. 1992. Regulating transcription factor activity by phosphorylation. Trends Cell Biol. 2: 104-108.

Jackson, S.P., J.J. MacDonald, S. Lees-Miller, and R. Tjian. 1990. GC box-binding induces phosphorylation of Spl by a DNAdependent protein kinase. Cell 63: 155-165.

Jones, S.W., E. Erikson, J. Blenis, J.L. Maller, and R.L. Erikson. 1988. A Xenopus ribosomal protein S6 kinase has two apparent kinase domains that are each similar to distinct protein kinases. Proc. Natl. Acad. Sci. 85: 3377-3381.

Karin, M. 1994. Signal transduction from the cell surface to the nucleus through the phosphorylation of transcription factors. Curr. Opin. Cell Biol. 6: 415-424.

Kilgour, E. and N.G. Anderson. 1994. Growth hormone induces the tyrosine phosphorylation and nuclear accumulation of components of the ISGF3 transcription factor complex. FEBS Lett. 343: 205-207.

Kipreos, E.T. and J.Y.J. Wang. 1992. Cell cycle-regulated binding of c-Abl tyrosine kinase to DNA. Science 256: 382-385.

Kozma, S.C., E. McGlynn, M. Siegmann, C. Reinhard, S. Ferrari, and G. Thomas. 1993. Active baculovinus recombinant $\mathrm{p} 70^{\mathrm{s} 6 \mathrm{k}}$ and $\mathrm{p} 85^{\mathrm{s} 6 \mathrm{k}}$ produced as a function of infectious response. I. Biol. Chem. 268: 7134-7138.

Kuiper, G.G. and A.O. Brinkmann. 1994. Steroid hormone receptor phosphorylation: Is there a physiological role? Mol. Cell. Endocrinol. 100: 103-107.

Kunkel, T.A. 1985. Rapid and efficient site-specific mutagenesis without phenotypic selection. Proc. Natl. Acad. Sci. 82: 488-492.

Laemmli, U.K. 1970. Cleavage of structural proteins during the assembly of the head of bacteriophage T4. Nature 227: 680685.

Leach, K.L., E.A. Powers, V.A. Ruff, S. Jaken, and S. Kaufmann. 1989. Type 3 protein kinase $C$ localization to the nuclear envelope of phorbol ester-treated NIH 3T3 cells. J. Cell Biol. 109: 685-695.

Lenormand, P., C. Sardet, G. Pages, G. L'Allemain, A. Brunet, and J. Pouyssegur. 1993. Growth factors induce nuclear translocation of MAP kinases ( $\mathrm{p} 42^{\text {mapk }}$ and $\mathrm{p} 44^{\text {mapk}}$ ) but not of their activator MAP kinase kinase (p45 mapkk) in fibroblasts. J. Cell Biol. 122: 1079-1088.

Levin, D.E., G.I. Hammond, R.O. Ralston, and J.M. Bishop. 1987. Two yeast genes that encode unusual protein kinases. Proc. Natl. Acad. Sci. 84: 6035-6039.

Lewis, R.E., G.P. Wu, R.G. MacDonald, and M.P. Czech. 1990. Insulin-sensitive phosphorylation of serine $1293 / 1294$ on the human insulin receptor by a tightly associated serine kinase. J. Biol. Chem. 265: 947-954.

Lin, Y.-S., and M.R. Green. 1991. Mechanism of action of an acidic transcriptional activator in vitro. Cell 64: 971-981.

Liu, J. 1993. FK506 and cyclosporin, molecular probes for studying intracellular signal transduction. Immunol. Today
14: $290-295$.

Lu, H., L. Zawel, L. Fisher, J.-M. Egly, and D. Reinberg. 1992. Human general transcription factor IIH phosphorylates the C-terminal domain of RNA polymerase II. Nature 358: 641645.

Maru, Y. and O.N. Witte. 1991. The BCR gene encodes a novel serine/threonine kinase activity within a single exon. Cell 67: 459-468.

Mazo, A.M., D.-H. Huang, B.A. Mozer, and I.B. Dawid. 1990. The trithorax gene, a trans-acting regulator of the bithorax complex in Drosophila, encodes a protein with zinc-binding domains. Proc. Nat1. Acad. Sci. 87: 2112-2116.

Miyoshi, H., T. Kozu, K. Shimizu, K. Enomoto, N. Maseki, Y. Kaneko, N. Kamada, and M. Ohki. 1993. The $t(8 ; 21)$ translocation in acute myeloid leukemia results in production of an AML1-MTG8 fusion transcript. EMBO $/$. 12: 2715-2721.

Moll, T., G. Tebb, U. Surana, H. Robitsch, and K. Nasmyth. 1991. The role of phosphorylation and the CDC28 protein kinase in cell cycle-regulated nuclear import of the S. cerevisiae transcription factor SWI5. Cell 66: 743-758.

Mozer, B.A. and I.B. Dawid. 1989. Cloning and molecular characterization of the trithorax locus of Drosophila melanogaster. Proc. Natl. Acad. Sci. 86: 3738-3742.

Nigg, E.A., H. Hilz, H.M. Eppenberger, and F. Dutly. 1985. Rapid and reversible translocation of the catalytic subunit of cAMP-dependent protein kinase type II from the Golgi complex to the nucleus. EMBO I. 4: 2801-2806.

Pearson, R.B. and B.E. Kemp. 1991. Protein kinase phosphorylation site sequences and consensus specificity motifs: Tabulations. Methods Enzymol. 200: 62-81.

Rechsteiner, M. 1988. Regulation of enzyme levels by proteolysis: The role of PEST regions. Adv. Enz. Regul. 27: 135-151.

1990. PEST sequences are signals for rapid intracellular proteolysis. Semin. Cell Biol. 1: 433-440.

Rechsteiner, M., S. Rogers, and K. Rote. 1987. Protein structure and intracellular stability. Trends Biochem. Sci. 12:390394.

Rihs, H.-P., D.A. Jans, H. Fan, and R. Peters. 1991. The rate of nuclear cytoplasmic protein transport is determined by the casein kinase II site flanking the nuclear localization sequence of the SV40 T-antigen. EMBO I. 10: 633-639.

Rushlow, C. and A. Warrior. 1992. The rel family of proteins. Bioessays 14: 89-95.

Schrag, J.D., Y. Li, S. Wu, and M. Cygler. 1991. Ser-his-glu triad forms the catalytic site of the lipase from Geotrichum candidum. Nature 351: 761-764.

Tamkun, J.W., R. Deuring, M.P. Scott, M. Kissinger, A.M. Pattatucci, T.C. Kaufman, and J.A. Kennison. 1992. brahma: A regulator of Drosophila homeotic genes structurally related to the yeast transcriptional activator SNF2/SWI2. Cell 68: $561-572$.

Tkachuk, D.C., S. Kohler, and M.L. Cleary. 1992. Involvement of a homolog of Drosophila trithorax by 11q23 chromosomal translocations in acute leukemias. Cell 71: 691-700.

Whiteside, S.T. and S. Goodbourn. 1993. Signal transduction and nuclear targeting: Regulation of transcription factor activity by subcellular localisation. J. Cell Sci. 104: 949-955.

Williams, N.G., T.M. Roberts, and P. Li. 1992. Both p21 ${ }^{\text {ras }}$ and pp60 $0^{\mathrm{v}-\mathrm{src}}$ are required, but neither alone is sufficient, to activate the Raf-1 kinase. Proc. Natl. Acad. Sci. 89: 29222926. 


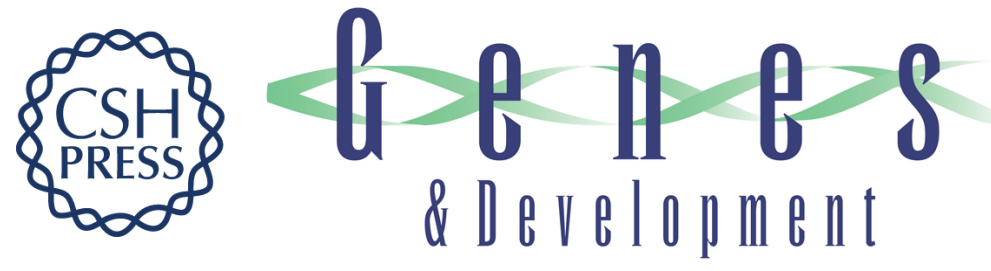

\section{A novel, mitogen-activated nuclear kinase is related to a Drosophila developmental regulator.}

$\mathrm{G} \vee$ Denis and M R Green

Genes Dev. 1996, 10:

Access the most recent version at doi:10.1101/gad.10.3.261

References This article cites 70 articles, 24 of which can be accessed free at: http://genesdev.cshlp.org/content/10/3/261.full.html\#ref-list-1

License

Email Alerting

Service

Receive free email alerts when new articles cite this article - sign up in the box at the top right corner of the article or click here.

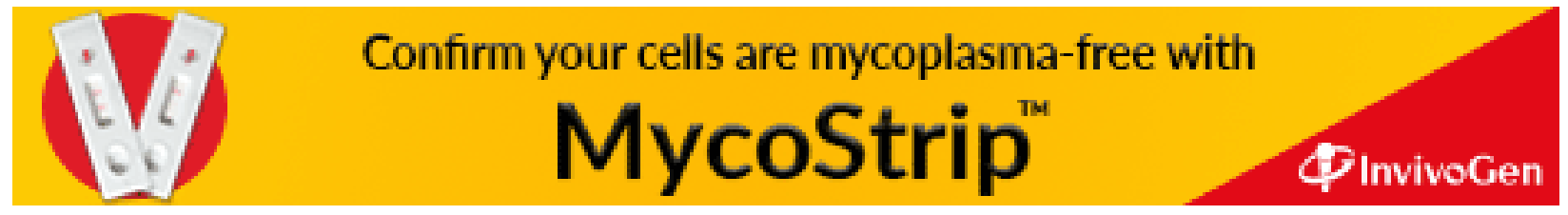

